\title{
Gender-induced Variation in L2 Production: The Case of Reference Terms
}

\author{
Musa Moradi \\ Department of English, Islamic Azad University, Bonab branch, Bonab, Iran \\ Email: musamoradi@yahoo.com \\ Azam Shahsavari \\ Department of English, Islamic Azad University, Khorramabad Branch, Lorestan, Iran \\ Email: shahsavariati36@yahoo.com \\ Mohammad Hossein Yousefi (Corresponding Author) \\ Department of English, Khorasgan (Isfahan) branch, Islamic Azad University, Isfahan, Iran \\ Email: mhh.yousefi@gmail.com
}

\begin{abstract}
Variation in language reception and production is one of the enduring problems of second language acquisition research. There are a number of sources of variation in L2 production. The present study addresses gender-prompted variation in the use of reference terms. Reference deals with the links between words and objects or events in the world. In discourse analysis, reference is use to tackle the links between words (or phrases) and other words (or phrases) in discourse. Reference terms are operationalized by using lexical noun phrases, common nouns, personal pronouns, indefinite articles, propositional phrases and the like. For the purpose of data collection forty EFL intermediate students (20 male students and 20 female students) participated in the preset study. Each participant transacted the narrative task in monologic condition with the second researcher. The results of the statistical analyses revealed that there have been significant differences between the mean of male group and female group in the use of reference terms.
\end{abstract}

Index Terms $-\mathrm{L} 2$ production, language variation, gender, reference terms

\section{INTRODUCTION}

Variation is one of the abiding problems of second language acquisition (Young, 1988). By variation, Mitchell \& Myles (2003, p.224) refer to the fact that second language learners commonly produce different versions of particular constructions more or less close to the target language forms, within a short time span (even, perhaps, within succeeding utterance). Variability is also an obvious feature of both child language and of learners' second language interlanguage, which has been noted and discussed in many studies (Mitchell \& Myles, 2003). Towell and Hawkins (1994) argued that it is one of the basic characteristics of interlanguage which SL learning theorists have to explain. There is a wide range of factors that have been invoked to explain patterns of interlanguage variability (Ellis, 1994; Mitchell \& Myles, 2003).

The phenomenon of variability has led to a considerable debate in the second language acquisition literature (Mitchell \& Myles, 2003; Romaine 2003). Romaine (2003) believes that second language variability is usually 'conditioned by multiple causes'. She lists a series of possible explanations for second language variability, which she, then, sub-divides into 'internal' and 'external' groups. Romaine's typology is summarized under two headings. No doubt, her 'internal' list is a combination of linguistic and sociolinguistic elements, while the 'external' list is entirely sociolinguistic in origin.

Preston (1996) believed that in a series of studies in the late 1960s and early 1970s (summarized in Labov, 1966), William Labov established an approach to quantitative studies of language variation. The central claim of this approach is that the alternative forms of linguistic elements do not occur randomly. The frequency of their occurrences is predicted by (1) the shape and identity of the element itself and its linguistic context, (2) stylistic level (defined operationally), (3) social identity, and (4) historical position (assuming that one form is on the way in, the other on the way out).

Sociolinguists have long been interested in the idea that current variation in a given language may reflect ongoing processes of language change (Adamson, 2009). The suggestion is that a new language rule may be implemented initially only in a particular linguistic environment, and can then spread step by step to other environments. Romaine (2003) suggests that first language transfer is also a source of linguistic variability in second language interlanguage. She cites a number of studies of the acquisition of the definite article in a range of European languages, by learners from different first language backgrounds (some with article systems, some without). Generally, these studies showed that learners whose first language has an article system make faster progress than those without (e.g. Italian first language vs. Turkish first language learners of second language German) (Romaine, 2003, pp. 419-20). 
According to a number of SLA researchers, style of learning and task-based variation is another dimension of variability in L2 production (Ellis 1994; Rahimpour 1997; Romaine 2003; Tarone, 1988). Tarone (1988) has suggested that second language learners control a number of varieties of second language, ranging from a more pidgin-like style used in informal and unmonitored speech to a more target-like 'careful style' used in tasks with a focus on form. For example, Tarone's own work showed that both Japanese first language and Arabic first language learners of English as a second language supplied the third-person singular verb inflection $-s$ more reliably in formal contexts. Albeit, Romaine (2003) concludes from her survey that stylistic variation is rather weak among second language learners, and also argues that the problems involved in trying to conflate attention or degree of monitoring (both psycholinguistic concepts) and the sociolinguistic concepts of style.

Other sources of variation in L2 production include the different conditions accompanying the task, such as attention and time pressure (Hulstijin \& Hulstijin, 1984), the amount of prior experience (Brown et al., 1984), the amount of planning time (Foster \& Skehan, 1999), task condition (Rahimpour, 1997), and task complexity (Robinson, 2003; Yousefi, 2009).

Systematic differences in the way people talk within a speech community can be seen among speakers with different demographic characteristics, who belong to different age groups, social classes, ethnic groups, and genders (Adamson, 2009). For example, words ending in -ing, such as running and darling, have an informal pronunciation (runnin', darlin') as well as a formal pronunciation (Adamson, 2009). Houston (1985) has found that middle-class speakers and women use the formal variant more often than working-class speakers and men. Adamson (2009) contends that perhaps the most studied example of socially patterned variation involves the deletion of the sounds / $\mathrm{t} /$ and /d/ when they occur in a consonant cluster in word final position, so that the words mist and buzzed are pronounced mis' and buzz'. A number of studies (Fasold, 1985; Wolfram, 1975) have found that men delete $/ \mathrm{t}, \mathrm{d} / \mathrm{more}$ often than women, that working-class speakers delete /t,d/ more often than middle-class speakers, and that almost all speakers delete /t, $\mathrm{d} / \mathrm{more}$ often when they are speaking informally. Wolfram (1975) came to the conclusion that different rates of /t,d/ deletion correlated with the social class of African American English (AAE) speakers living in Detroit (who can delete /t, d/ from non-clusters, so that did can be pronounced [di]). It is shown in Wolfram (1975) that $/ \mathrm{t}, \mathrm{d} /$ deletion rates range from 51 percent for upper-middle-class speakers to 84 percent for lower-working-class speakers.

Adamson (2009), likewise, believes that the frequency at which a speaker uses variable forms depends not only on the speaker's demographic characteristics, but also on the linguistic environment in which the form occurs. Many studies have found that the frequency at which a variable feature is used also depends on the circumstances of speaking. Perhaps a good example is Labov's (1966) study of /r/ deletion in New York City. New Yorkers can delete / r/ after a vowel (so that forth floor is pronounced [fo: $\theta$ flo:]). Labov found that this deletion correlated not only with the linguistic environment and the speaker's social class but also with the speaking task. Labov suggested that the speakers tended to delete /r/ more in the casual style because they paid less attention to how they sounded, concentrating instead on telling the story. However, in formal style the speakers monitored their speech, trying to avoid stigmatized forms like deleted $/ \mathrm{r} /$.

Romaine (2003) comments that second language variability is usually 'conditioned by multiple causes'. As it was mentioned earlier, she sub-divides possible explanations for second language variability into 'internal', and 'external' groups. Her 'internal' list is a combination of linguistic and sociolinguistic elements, while the 'external' list is totally sociolinguistic in origin. In the same vein, Ellis (1994) discusses the sources of variation in interlanguage under the headings of systematic and non-systematic variation. For Ellis (1994) systematic variations include; 'psycholinguistic context', 'linguistic context', and 'external or situational context'. On the other hand, Ellis has argued that some variation in second language performance is simply free or random. Tarone (1979) pointed out that language varies with subtle shifts of the situation, just as a chameleon changes color as its surrounding changes. Tarone (1979) then proposes that the interlanguage of L2 learners should be viewed as a variable system, a system that changes when the linguistic environment changes.

\section{Gender-based Variation}

First of all, it seems imperative to make a distinction between sex and gender. The term 'sex' has often been used to refer to the physiological distinction between females and males, with 'gender' referring to the social and cultural elaboration of the sex difference - a process that restricts our social roles, opportunities and expectations (West \& Zimmerman 1987). Since the process begins at birth, it could be argued that 'gender' is the more appropriate term to use for the category than 'sex' (Cheshire, 1999).

There has been considerable scholarly interest in issues related to gender. There is a considerable body of research that suggests that male and female college students experience the online classroom environment differently (Allen, 1994; Barber, Sullivan \& Walker, 1997; Selfe, 1999; Sullivan, 1999; Wojahn, 1994; Wolfe, 1999). As one of the popular fields in sociolinguistics, explorations on gender difference in English language and other languages as well have experienced a period of gradual development (Ning .et al, 2010). In the early 1970s, American linguist Robin Lakoff proposed that American women were constrained to soften and attenuate their expression of opinion through such devices as: tag questions, rising intonation on declaratives, the use of various kinds of hedges, boosters or amplifiers, indirection, diminutives (panties), euphemism, and conventional politeness, especially forms that mark 
respect for the addressee (Lakoff, 1972). Overall then, Lakoff (1972) suggested, a distinctive part of speaking 'as a woman' is speaking tentatively, side stepping firm commitment and the appearance of strong opinions.

Ning et al (2010) asserted that in terms of intonation, men and women also display some difference. It is more frequent that female speakers tend to command a wider range of intonation, making their speech sound somewhat affected. It is also discovered that females tend to use the low-rise intonation with statements more frequently than male speakers do. They also discussed differences in terms of Vocabulary, Topic-Selection, Difference in Giving Orders, Difference in Request Patterns, Difference in Amount of Talk, and Difference in Attitudes in Face of Unlucky Events or Complaints.

As far as the causes of the differences between male and female language are concerned, Ning et al (2010) have attributed these differences to: Early Childhood Socialization, Cultural and Social Expectation, Different Role of Language as for Men and Women, and Physiological and Psychological Factors. Gender differences can be traced in other areas such as the language of emotion. O'Kearney (2004) says: "there are clear gender differences in emotion display rules with males preferring behavioral and action/expressive modes and women preferring verbal and facial expressive mode" (p. 915). Males focus less on the consequences and resolution of conflict than women and have a higher priority for more immediate, behavioral representations of their emotional responses.

Rong \& Yu Hsieh (2007) showed that women may have a greater difference between semantic knowledge and the episodic emotion experience than man do. Women are more emotional than men, so they have better conceptual knowledge in emotional terms; however, with the description of their experiences, women tend to use detailed and specific terms which are not as abundant as the basic emotional terms.

Within the social sciences, an increasing consensus of findings suggests that men, relative to women, tend to use language more for the instrumental purpose of conveying information; women are more likely to use verbal interaction for social purposes with verbal communication serving as an end in itself (e.g., Brownlow, Rosamon, \& Parker, 2003; Colley et al., 2004).

Some researchers (e.g., Mulac, Weimann, Widenmann, \& Gibson, 1988) found that questions are more common in women's contributions to dyadic interactions (e.g., "Does anyone want to get some food?"), whereas directives that tell the audience to do something (e.g., "Let's go get some food") are more likely to be found in men's conversational contributions.

Narratives

There are a number of reasons for prevalence and universality of narratives both in the language of children and L2 speakers. Berman (2004) advanced three reasons in favor of narrative in child language. First, narrative discourse is appropriate for the investigation of children's language beyond the boundaries of single utterance in naturalistic speech or of isolated sentences in structured elicitations. Second, narratives are a universal type of discourse, familiar to children raised in oral as well as literate cultures (Bavin, 2004). Third, they share variegated range of numerous subgenres, fictive (romance, mystery, etc.) and veridical (autobiography, history, etc.).

Since the present study takes narrative functions rather than linguistic forms as the departure for analysis, reference to participants in a story, by means of nominal constructions like lexical NPs and pronouns, common nouns, personal pronouns, indefinite articles, and propositional phrase are taken into consideration.

The term 'reference' serves the meaning of relating to entities mentioned in a piece of discourse (Berman, 2009). Linguistically, reference can be realized by lexical noun phrases, proper nouns, common nouns and complex noun phrases with adjectives, propositional phrases and/or relative clauses, and also by personal or lexical substitution (Berman, 2009). Reference deals with the links between words and objects or events in the world. In discourse, reference deals with the links between words (or phrases) and other words (or phrases) in discourse (Bermanl, 2009). In other words, reference is a semantic relation whereby information needed for the interpretation of one item is found elsewhere in the text. Reference creating in a discourse has also other functions as developing contextuality and closer binding of individual utterances in a piece of discourse.

In order for interlocutors to understand who are or what is being talked about as the narrative proceeds, these characters need to be suitably introduced as new participants in the story, re-referenced to by maintaining reference to them, or marked by shifting reference to other participants (Berman, 2009). Referring expressions consist of 'cohesive ties' (Halliday \& Hasan, 1976) that serve to link utterances together in a text.

\section{Methodology}

\section{A. Research Questions}

The present study addresses the following research questions:

1. Is there a significance difference in the mean of male group and female group in the use of reference terms in terms of Lexical noun Phrases?

2. Is there a significance difference in the mean of male group and female group in the use of reference terms in terms of Common Nouns?

3. Is there a significance difference in the mean of male group and female group in the use of reference terms in terms of personal pronouns? 
4. Is there a significance difference in the mean of male group and female group in the use of reference terms in terms of indefinite articles?

5. Is there a significance difference in the mean of male group and female group in the use of reference terms in terms of propositional phrases?

Following research procedures, the following null hypotheses are presented and then evaluated against the obtained data from research subjects:

HO 1. There is not a significance difference in the mean of male group and female group in the use of reference terms in terms of Lexical noun Phrases.

HO 2. There is not a significance difference in the mean of male group and female group in the use of reference terms in terms of Common Nouns.

HO 3. There is not a significance difference in the mean of male group and female group in the use of reference terms in terms of personal pronouns.

HO 4. There is not a significance difference in the mean of male group and female group in the use of reference terms in terms of indefinite articles.

HO 5. There is not a significance difference in the mean of male group and female group in the use of reference terms in terms of propositional phrases.

\section{B. Instruments}

For the purpose of the data collection, a pedagogical task was used. The task illustrated four different pictures in a chronological order. The students had to tell a story based on the pictures. The task required the participants to refer to people and things in the story. Hence, the Participants had to refer to different objects and people and different roles assigned to the characters in the story. (See, appendix).

\section{Participants}

The participants recruited for the purpose of the present study were 40 learners who enrolled in a university undergraduate second semester. They were 20 male and 20 female students aged between 21 and 26 (mean=22.5). They had Turkish and Kurdish as their first language and had already learned Persian as their second language. They had exposure to English language instruction as calls Focus on Forms for seven successive years at school. They only had been at the exposure of English communicative skills for two successive semesters at university.

\section{Procedure}

In performing the pedagogic task, participants sat at a table looking at the picture. No other people, apart from each participant and the researcher were present. And the data collection was conducted in a quiet room in the second office at university. Having gathered personal information and achieving rapport with the participants, the researcher told them about the demands of the task and the participants performed the specified task in monologic condition. Apart from age and first language background, no personal information was sought. Each participant was given up to five minutes to do the required task. The whole procedure of task performance was audiotaped and the process of transcribing and coding and analyzing the collected data were done through using personal computer.

\section{RESUlTS AND FINDINGS}

As Table 1 shows, as far as the use of the 'lexical noun phrase' is concerned, the mean for the male group is 9.85, whereas, the mean of this category for female group is 7.40. With respect to the use of 'common noun', the mean of the male group is 2.45 , while the mean for the female group is 7.15 . For 'personal pronouns', the mean of male is 10.40 while the mean of female is 12.70 . For 'indefinite articles', the mean of male group is .75 whilst the mean of the female group in this category is 2.00. As far as the use of 'propositional phrase' is considered, the mean for male group is .90 , while this is 4.00 for the female group.

TABLE 1.

GROUP STATISTICS FOR COMPARING MALE AND FEMALE GROUPS IN THE USE OF REFERENCE TERMS

\begin{tabular}{|l|l|l|l|l|l|}
\hline Category & gender & $\mathbf{N}$ & Mean & Std. Deviation & Std. Error Mean \\
\hline Lexical noun & male & 20 & 9.85 & 3.528 & .789 \\
Phrase & Female & 20 & 7.40 & 2.683 & .600 \\
\hline Common noun & male & 20 & 2.45 & 1.234 & .276 \\
& female & 20 & 7.15 & 2.368 & .530 \\
\hline Personal pronounce & male & 20 & 10.40 & 2.741 & .613 \\
& female & 20 & 12.70 & 4.194 & .938 \\
\hline Indefinite article & male & 20 & .75 & 1.164 & .260 \\
& female & 20 & 2.00 & 1.864 & .417 \\
\hline Propositional & male & 20 & .90 & .718 & .161 \\
Phrase & female & 20 & 4.00 & 2.428 & .543 \\
\hline
\end{tabular}

Using the data in table 2, the following results can be concluded: 
1. The null hypothesis stating that the means of male group is not significantly different from the mean of female group in the use of 'lexical noun phrases' is rejected since the amount of $t$ at the level of $(\mathrm{p}=.05)$ and $(\mathrm{df}=38)$ is significant.

2. For the second category ('common nouns'), the amount of $t$ at the level of $(\mathrm{p}=.05)$ is also statistically significant, thus the null hypothesis stating that that the means of male group is not significantly different from the mean of female group in the use of common nouns is rejected.

3. For the third category ('personal pronouns'), the amount of $t$ at the level of $(\mathrm{p}=.05)$ and $(\mathrm{df}=38)$ is statistically significant, too. Thus the null hypothesis stating that that the means of male group is not significantly different from the mean of female group in the use of 'personal pronouns' is rejected.

4. For the fourth category ('indefinite articles'), the amount of $t$ at the level of $(\mathrm{p}=.05)$ and $(\mathrm{df}=38)$ is statistically significant, thus the null hypothesis stating that that the means of male group is not significantly different from the mean of female group in the use of 'indefinite articles' is rejected, too.

5. As far as the last category ('propositional phrases') is concerned, the amount of $t$ at the level of $(\mathrm{p}=.05)$ and $(\mathrm{df}=38)$ is statistically significant, thus the null hypothesis stating that that the means of male group is not significantly different from the mean of female group in the use of 'propositional phrases' is also rejected.

TABLE 2.

INDEPENDENT SAMPLES T-TEST FOR COMPARING REFERENCE TERMS IN MALE AND FEMALE GROUPS

\begin{tabular}{|c|c|c|c|c|c|c|c|}
\hline & \multicolumn{7}{|c|}{ t-test for Equality of Means } \\
\hline & \multirow[b]{2}{*}{$\mathbf{t}$} & \multirow[b]{2}{*}{ df } & \multirow[b]{2}{*}{$\begin{array}{l}\text { Sig.(2- } \\
\text { tailed) }\end{array}$} & \multirow[b]{2}{*}{$\begin{array}{l}\text { Mean } \\
\text { Difference }\end{array}$} & \multirow[b]{2}{*}{$\begin{array}{l}\text { Std. Error } \\
\text { Difference }\end{array}$} & \multicolumn{2}{|c|}{$\begin{array}{l}\text { 95\% Confidence Interval of the } \\
\text { Difference }\end{array}$} \\
\hline & & & & & & Lower & Upper \\
\hline Lexical noun & 2.472 & 38 & .018 & 2.450 & .991 & .443 & 4.457 \\
\hline Phrase & 2.472 & 35.468 & .018 & 2.450 & .991 & .439 & 4.461 \\
\hline Common & -7.871 & 38 & .000 & -4.700 & .597 & -5.909 & -3.491 \\
\hline noun & -7.871 & 28.615 & .000 & -4.700 & .597 & -5.922 & -3.478 \\
\hline Personal & -2.053 & 38 & .047 & -2.300 & 1.120 & -4.568 & -.032 \\
\hline pronounce & -2.053 & 32.730 & .048 & -2.300 & 1.120 & -4.580 & -.020 \\
\hline Indefinite & -2.544 & 38 & .015 & -1.250 & .491 & -2.245 & -.255 \\
\hline article & -2.544 & 31.867 & .016 & -1.250 & .491 & -2.251 & -.249 \\
\hline Propositional & -5.476 & 38 & .000 & -3.100 & .566 & -4.246 & -1.954 \\
\hline Phrase & -5.476 & 22.300 & .000 & -3.100 & .566 & -4.273 & -1.927 \\
\hline
\end{tabular}

\section{CONCLUSION}

The present study showed that the language second language learners use to refer to things and people in their speech is significantly different for male and female groups. In this study, we operationalized reference terms in the forms of employing lexical noun phrases, common nouns, personal pronouns, indefinite articles, and propositional phrases. The findings of the study are in line with (Brownlow, Rosamon, \& Parker, 2003; Colley et al., 2004) in that the language produced by men is different from the language uttered by women.

It is suggested that other studies can employ other ways to operationalize using the reference terms on the part of L2 speakers. The present study employed one type of task to elicit L2 production; other studies are called to investigate different task types with different linguistic or discourse orientation to collect data on gender-prompted variation L2 production. Further studies are also required to investigate different dimensions of discourse-embedded L2 production especially with respect to narratives. Finally, because of the prevalence of narratives in language production, other studies can investigate certain features of narratives and their contribution to interlanguage development. 


\section{APPENDIX}

Test I Speaking
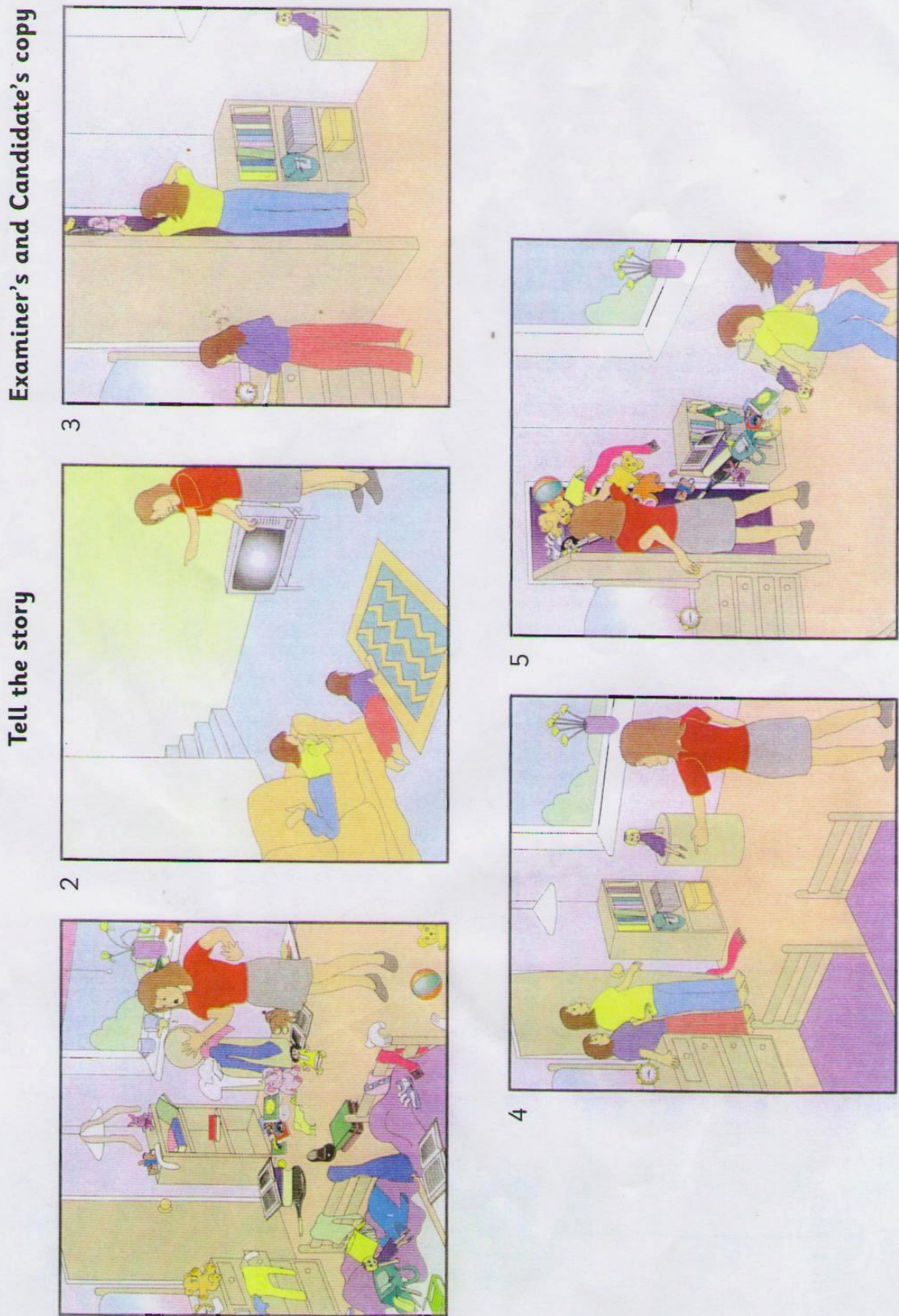

เก

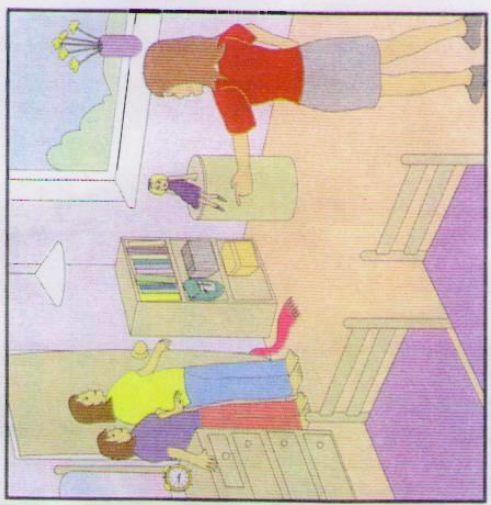

$\checkmark$

\section{REFERENCES}

[1] Adamson. H. D. (2009). Interlanguage variation in theoretical and pedagogical perspective. New York: Routledge.

[2] Allen, M. (1994). Adventures with 'Robin Hood': Gender Conict on a .rst-year bulletin board. Journal of Teaching Writing, 13, 169- 196.

[3] Barber, M., Sullivan, L., \& Walker, J. (1997). Body, identity, and access: Diversity and networked environments [Letter from the guest editors]. Computers and Composition, 14 (Special issue), 163-167. 
[4] Bavin, E. L., (2004). Focusing on 'where': An analysis of Warlpiri frog stories. In S. Stromqvist \& L. Verhoeven (Eds.), Relating Events in Narrative: Typological and Contextual Perspectives (pp. 17-35). Mahwah, NJ: Lawrence Erlbaum Associates.

[5] Berman, R. (Ed.). (2004). Language Development across Childhood and Adolescence. Philadelphia, PA: John Benjamins.

[6] Berman, r. (2009). Language development in narrative contexts. In Bavin, E, L. (ed). The Cambridge handbook of child language. Camdridge University press.

[7] Brown, G. Anderson, A. Shillcock, R. and Yule, G. (1984). Teaching talk: strategies for production and Assessment. Cambridge 196. University Press.

[8] Brownlow, S., Rosamon, J. A., \& Parker, J. A. (2003). Gender-linked linguistic behavior in television interviews. Sex Roles, 49, 121-132.

[9] Cheshire, J. (1999). Spoken Standard English. In A.R. Bex and R.J. Watts (eds.) Standard English: The Continuing Debate (pp. 129-145). London: Routledge.

[10] Colley, A., Todd, Z., Bland, M., Holmes, M., Khanom, M., \& Pike, H. (2004). Style and content in emails and letters to male and female friends. Journal of Language and Social Psychology, 23, 369-378.

[11] Ellis, R.( 1994). The study of second language acquisition. Oxford: Oxford University Press.

[12] Fasold, R. (1985). Perspectives on sociolinguistic variation. Language in Society, 14, 515-526.

[13] Foster, P., \& Skehan, P. (1999). The influence of source of planning and focus of planning on task-based performance. Language Teaching Research, 3, 215-247.

[14] Halliday, M. A. K., \& Hasan, R. (1976). Cohesion in English. London: Longman.

[15] Houston, S. (1985). Continuity and change in English morphology: The variable ING. Unpublished doctoral dissertation. University of Pennsylvania.

[16] Hulstijin, J. and Hulstijin, W. (1984). Grammatical errors as function of processing constraints and explicit knowledge. Language learning, 43, 23-43.

[17] Labov, W. (1966). The social stratification of English in New York City. Washington, DC: Center for Applied Linguistics.

[18] Lakoff, R. (1972). Language in context. Language, 48:907--924. 1975. Language and Woman's Place. New York: Harper and Row.

[19] Mitchell, R., and Myles, R. (2003). Second Language Learning Theories. London: Edward Arnold.

[20] Mulac, A., Wiemann, J. M., Widenmann, S. J., \& Gibson, T. W. (1988). Male/female language differences and effects in samesex and mixed-sex dyads: The gender-linked language effect. Communication Monographs, 55, 315-335.

[21] Ning, H, X. Dai \& f. Zhang (2010) . On Gender Difference in English Language and Its Causes. Asian Social science. Vol 6. No.2. 126-130.

[22] O'Kearney, R., \& Dadds, M. (2004). Developmental and gender differences in the language for emotions across the adolescent years. Cognition and Emotion, 18(7), 913-938.

[23] Preston, D.(1996). Variationist linguistics and second language acquisition in Ritchie \& Bhatia (Eds). The handbook of second language acquisition. Academic press, US.

[24] Rahimpour, M. (1997). Task complexity, task condition and variation in L2 oral discourse. Unpublished PhD Thesis. The University of Queensland, Brisbane, Australia.

[25] Robinson, P. (2003). The Cognition Hypothesis, task design and adult task-based language learning. Second Language Studies, 21(2), 45-107.

[26] Rong, W. \& S. Yu Hsieh (2007). gender differences in the language for emotions. Asian Journal of Management and Humanity Sciences, Vol. 2, Nos. 1-4, pp. 89-97, 2007

[27] Romaine, S. 2003: Variation. In Doughty, C.J. and Long, M.H. (eds), The handbook of second language acquisition. Oxford: Blackwell Publishing, 409-35.

[28] Selfe, C. (1999). Technology and literacy: A story about the perils of not paying attention. College Composition and Communication, 50, 411-436.

[29] Tarone, E. (1988). Variation in interlanguage. London: Edward Arnold.

[30] Towell, R. and Hawkins, R. (1994). Approaches to second language acquisition. Clevedon: Multilingual Matters.

[31] West, C. \& D. Zimmerman. (1987). Doing gender. Gender and Society, 1:125--151.

[32] Wolfram, W. (1975). Variable constraints and rule relations. In R. W. Fasold \& R. W. Shuy, (Eds.), Analyzing variation in language (pp. 70-88). Washington, DC: Georgetown University Press.

[33] Wolfe, J. (1999). Why do women feel ignored? Gender differences in computer-mediated classroom interactions. Computer and Composition, 16(1), 153-166.

[34] Young, R. (1988). Variation and the interlanguage hypothesis. Studies in second language Acquisition, 10, 281-302.

[35] Yousefi, M. H. (2009). The effect of task complexity on learner uptake. Unpublished M. A. Thesis. University of Tabriz, Iran.

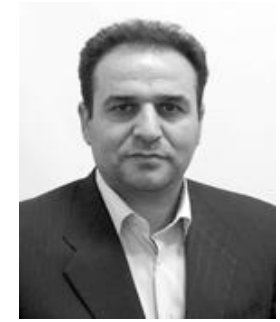

Musa Moradi has taught English for undergraduate students for more than 15 years. He has presented and published a number of papers. His fields of interests are: SLA, and the role of interactional feedback in L2 acquisition. For the time being, he is a faculty member and the deputy of financial affairs at Islamic Azad University, Bonab Branch, Iran. 


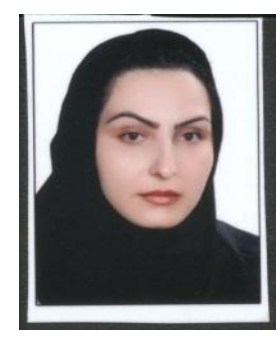

Azam Shahsavari is currently a PhD candidate in General Linguistics at Islamic Azad University, Science and Research Branch in Tehran, Iran. She has written books and published papers in domestic and international journals. Her areas of interest include pronunciation and vocabulary acquisition, syntax, semantics, discourse analysis, dialectology, sociolinguistics, and psycholinguistics.

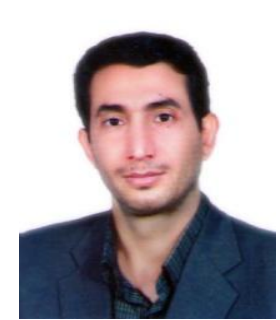

Mohammad Hossein Yousefi is currently doing his $\mathrm{PhD}$ at the Islamic Azad University of Khorasgan (Isfahan), Iran. His main research interests are; Task-based Language Teaching, Cognitive Complexity, Corrective Feedback, and SLA. He, also, teaches ESP for undergraduate students at the Islamic Azad University of Bonab, Iran. 